\title{
PERLINDUNGAN HUKUM PROFESI DOKTER DALAM PENYELESAIAN SENGKETA MEDIS
}

\author{
dr. Setyo Trisnadi \\ Dekan Fakultas Kedokteran Unissula Semarang \\ Setyotrisnadi unissula@yahoo.com
}

\begin{abstract}
This study aims to explore the analysis of the application of legal protection and its weaknesses in the settlement of medical disputes between physicians and patients today. Descriptively analytical and empirical juridical approaches, and using constructivism paradigm, it is hoped that the authors can describe various primary and secondary data to reconstruct the legal protection of the physician profession in the settlement of medical dispute between physicians and patients based on the value of justice. In the resolution of medical disputes between physicians and patients as set forth in Article 50 of Law No. 29 of 2004 on Medical Practice and Article 57 Law No. 36 Years of Health Personnel has not fully provided protection for doctors, because in practice the handling of alleged malpractice cases by the police investigator will certainly use the procedures or procedures in the KUHAP as a reference, this is because the Law does not regulate how to be in the event of suspicion that doctors violate articles In UUPK. The Government and House of Representatives are expected to make improvements to Law No. 29 of 2004 on Medical Practice, by making regulations on "procedural arrangements" ranging from inquiry, investigation, prosecution if necessary to verdict.
\end{abstract}

\begin{abstract}
Abstrak
Studi ini bertujuan untuk menggali analisa dalam penerapan perlindungan hukum dan kelemahan-kelemahannya dalam penyelesaian sengketa medis antara dokter dan pasien saat ini. Secara deskriptif analitis dan pendekatan yuridis empiris,serta menggunakan paradigm konstruktivisme, diharapkan penulis dapat menguraikan berbagai data primer maupun sekunder guna merekonstruksi perlindungan hukum profesi dokter dalam penyelesaian sengketa medis antara dokter dan pasien yang berbasis nilai keadilan. Dalam penyelesaian sengketa medis antara dokter dan pasien sebagaimana tertuang dalam Pasal 50 Undang-Undang No. 29 Tahun 2004 tentang Praktik Kedokteran dan Pasal 57 Undang-Undang No. 36 Tahun tentang Tenaga Kesehatan belum sepenuhnya memberikan perlindungan bagi dokter, karena dalam praktiknya penanganan kasus dugaan malpraktik oleh penyidik kepolisian tentunya akan menggunakan tatacara atau prosedur yang ada di KUHAP sebagai acuannya, ini dikarenakan UUPK tidak mengatur bagaimana beracaranya apabila ada dugaan dokter melanggar pasal-pasal dalam UUPK. Pemerintah dan DPR diharapkan dapat melakukan penyempurnaan terhadap UndangUndang No. 29 Tahun 2004 tentang Praktik Kedokteran, dengan dibuatnya peraturan tentang "tatacara beracara" mulai dari penyelidikan, penyidikan, penuntutan jika diperlukan dengan sampai putusan.
\end{abstract}

\section{A. Pendahuluan}

Dalam hubungan terapeutik (professional conduct), sengketa medis di Indonesia dipicu oleh adverse event (kejadian tidak diharapkan) dan menjadi opini bahwa setiap adverse event digeneralisasi adalah malpraktik, ${ }^{1}$ hal ini dipengaruhi oleh faktor internal maupun

\footnotetext{
1 Breen, J, K et.al, 2010, Good Medical Practice Professionalism, Ethics And Law, Cambridge University Press, New york, h. 49.
} 
eksternal pasien. Kasus dugaan malpraktik yang dilaporkan ke Konsil Kedokteran Indonesia kurun waktu tahun 2006-2015 sebanyak 317 kasus, 114 diantaranya adalah dokter umum, disusul dokter bedah 76 kasus, dokter obsgyn (spesialis kandungan) 56 kasus dan dokter spesialis anak 27 kasus. ${ }^{2}$ Di wilayah IDI Jawa Tengah selama tahun 2011-2014 sebanyak 6 kasus, diantaranya adalah dugaan malpraktik di RSU Santa Maria Pemalang. Proposisi ini didasarkan pada doktrin hukum kelalaian (doctrine of negligence) yaitu res ipsa loquitur atau "the thing speaks for itself' . ${ }^{3}$ Doktrin ini hanya berlaku dan tepat penerapannya hanya untuk lapangan hukum perdata dengan konsep tanpa pembuktian atas terjadinya kelalaian atau kesalahan perihal perbuatan melawan hukum (onrechtmatige daad) antara pasien sebagai penggugat atas kesalahan dari dokter sebagai tergugat. ${ }^{4}$

Persoalannya sekarang ialah, apakah kelalaian dalam menjalankan praktik perobatan dapat dikatagorikan sebagai medico-crime? Jawabannya terpulangkan kepada kita semua. Tetapi yang jelas di negara-negara common law (negara yang hukumnya selain statute law juga common law) tidak memidanakan dokter yang melakukan kelalaian dalam melaksanakan praktik perobatan. Jika kita hendak meniru negara common law maka perlu ada undang-undang yang bersifat lex

2 Untuk beberapa kasus malpraktek dokter di Indonesia dapat dilihat di http://www.merdeka.com/ peristiwa/5-kasus-malpraktek-dalam-dunia-kedokteran. html, diakses 5 Desember 2014

3 "Strict liability is absolute legal responsibility for an injury that can be imposed on the wrongdoer without proof of carelessness or fault', lihat http:// legal-dictionary.thefreedictionary.com/Strict+Liability, diakses 5 Desember 2014.

4 Dalam Black Law's dictionary dikatakan bahwa :"Res ipsa loquitur is an appropriate form of circumstantial evidence enabling the plaintiff in particular cases to establish the defendantıs likely negligence. Hence the res ipsa loquitur doctrine, properly applied, does not entail any covert form of strict liability ... The doctrine implies that the court does not know, and cannot find out, what actually happened in the individual case. Instead, the finding of likely negligence is derived from knowledge of the causes of the type or category of accidents involved." Restatement (Third) of Torts $\S 15 \mathrm{cmt}$. a (Discussion Draft 1999), Blackıs Law Dictionary, Bryan A. Garner Editor in Chief Ninth Edition, 2009, st. Paul. MN West Pubushing. Co, h. 1425. specialis yang bisa mengabaikan Pasal 359 dan Pasal 360 KUHP. Selain itu pasal dalam UU Praktik Kedokteran yang mengkriminalkan dokter melakukan praktik perobatan di bawah standar juga perlu direkonstruksi, kebijakan dalam pasal tersebut berupa delik formiel (bukan delik materiel) yang dirasa berat bagi dokter.

Perlindungan hukum profesi dokter sudah diatur dalam undang-undang, yaitu: Pasal 50 UUPK, dokter atau dokter gigi dalam melaksanakan praktik kedokteran mempunyai hak: memperoleh perlindungan hukum sepanjang melaksanakan tugas sesuai dengan standar profesi dan standar prosedur operasional. Akan tetapi terdapat juga kriminalisasi profesi dokter dalam Pasal 76 dan pasal pidana lainnya UUPK "Setiap dokter atau dokter gigi yang dengan sengaja melakukan praktik kedokteran tanpa memiliki surat izin praktik sebagaimana dimaksud dalam Pasal 36 dipidana dengan pidana penjara paling lama 3 (tiga) tahun atau denda paling banyak Rp100.000.000,00 (seratus juta rupiah)". ${ }^{5}$ Pasal 359 KUHP berbunyi "Barang siapa karena kealpaannya menyebabkan matinya orang lain, diancam dengan pidana penjara paling lama lima tahun atau kurungan paling lama satu tahun". 6

Penelitian ini bertujuan untuk Untuk menganalisis penerapan per lindungan hukum dan kelemahan-kelemahan penerapan perlindungan hukum profesi dokter dalam penyelesaian sengketa medis antara dokter dan pasien saat ini. Selain itu penelitian ini juga menganalisa mengenai rekonstruksi perlindungan hukum profesi dokter dalam penyelesaian sengketa medis antara dokter dan pasien yang berbasis nilai keadilan.

Metodologi deskriptif analitis digunakan sebagai pisau analisa guna menjelaskan gambaran tentang rekonstruksi hukum pelindungan profesi dokter dalam penyelesaian sengketa medis. Melalui pendekatan yuridis empiris dan menggunakan paradigm konstruktivisme, diharapkan penulis dapat menguraikan berbagai data primer maupun sekunder diolah dan dianalisa guna merekonstruksi perlindungan hukum profesi dokter dalam penyelesaian sengketa medis

\footnotetext{
5 Undang-Undang No. 29 Tahun 2004 tentang Praktik Kedokteran.

6 Kitab Undang-Undang Hukum Pidana.
} 
antara dokter dan pasien yang berbasis nilai keadilan. Sehingga pandangan yang semula menggeneralisasi semua tindakan dokter, dikonstruksi kembali dengan prinsip, standar, aturan sehingga dokter yang berstandar harus dilindungi juga pasien terlindungi.

Studi kepustakaan dan obeservasi terhadap berlakunya UU Nomor 29 Tahun 2004 tentang Praktik Kedokteran, serta wawancara mendalam digunakan penulis untuk mengumpulkan data pendukung penelitian. Wawancara mendalam dengan sample dengan prinsip snowball, dengan metode penentuan sampel penelitian berdasarkan purposive non random sampling : Ketua IDI, Direktur Rumah Sakit Umum Santa Maria Pemalang, Dokter Tergugat, Keluarga pasien/masyarakat, Kepolisian Resor Pemalang, Pengadilan Negeri Pemalang.

Seluruh data yang telah berhasil peneliti kumpulkan baik data primer maupun sekunder akan dilakukan editing, koding serta penyajian data. Editing dilakukan peneliti dengan tujuan apakah data yang terkumpul sudah memenuhi harapan dan sesuai dengan yang diharapkan oleh peneliti. Dari editing kemudian dilakukan koding yaitu memisahkan data sesuai dengan kategori untuk mempermudah dalam melakukan klarifikasi.Model klasifikasi yang peneliti gunakan adalah Mattew B.Milles and A. Michael Huberman, yakni model yang bergerak dalam 3 siklus kegiatan yaitu reduksi data, penyajian data dan penarikan simpulan atau verifikasi. Setelah data disajikan kemudian dilakukan rekonstruksi serta menganalisanya secara kualitatif induktif untuk menjawab permasalahan yang terjadi pokok bahasan dalam penelitian ini $^{7}$. Guna mengetahui kevalidan data dalam penelitian ini akan ditempuh validasi dengan cara triangulasi data yaitu cek silang antara data yang satu dengan data yang lain baik yang diperoleh dari hasil studi pustaka dari literature, observasi dan wawancara ${ }^{8}$.

Mattew B. Milles and A. Michael Huberman, 2009, Analisis Data Kwalitatif, Buku Sumber Tentang Metode-Metode Baru, Penerjemah : Tjetjep Rohendi Rohidi, UI Press, Jakarta, h. 43.

8 Tohir M, 2007, Memahami Kebudayaan , Teori, Metodologi, dan Aplikasi, Fasindo Press, Semarang, h. 68-71.

\section{B. Pembahasan}

1. Kajian Hubungan Terapeutik dan Aspek Hukum.

Hubungan terapeutik yaitu suatu hubungan paternalistik/kekeluargaan atas dasar kepercayaan, hubungan seperti itu memiliki hubungan komparatif dibanding model hubungan yang didasarkan atas prinsip-prinsip hukum semata. Hubungan terapeutik sebagai hubungan kontraktual yang menghasilkan perikatan antara penyedia dan penerima jasa layanan medis, penyedia layanan medis wajib memberikan prestasinya sedangkan penerimanya wajib memberikan kontra-prestasi, secara khusus maka akan berlaku jenis perikatan yang lazim yaitu inspaning verbintenis dimana dokter hanya dituntut untuk memberikan prestasinya berupa "upaya medis" yang layak berdasar teori kedokteran.

Jika terjadi konflik antara penyedia jasa layanan medis dan penerimanya sekarang ini banyak orang memilih hukum sebagai acuan sebab hukum memiliki konsep yang jelas, instrumen yang memadai serta memiliki kekuatan guna melaksanakan keputusannya. Hanya saja penyelesaian lewat jalur hukum sangat birokratik, membutuhkan waktu lama dan biaya yang tidak sedikit. Bentuk penyelesaiannya pun sangat kaku dan kadang dapat menyakitkan salah satu atau bahkan kedua belah pihak. Oleh sebab itu hendaknya jalur hukum dipikirkan sebagai pilihan terakhir setelah upaya lainnya tidak memuaskan.

\section{Kajian Hubungan Terapeutik Dari Aspek Etik.}

Etika normatif menciptakan dua teori yaitu teori teleologi dan teori deontologi. ${ }^{9}$ Teori deontologi adalah teori tentang kewajiban, merupakan cabang ilmu etika berguna untuk etika profesional para pekerja medis. Etika ini diarahkan untuk menjamin hasil maksimum pengobatan. Sedangkan, teleologi adalah ilmu tentang hubungan dengan Ilahi (atau ideal, atau kekal tak berubah) dengan dunia fisik. Kumpulan ajaran mana saja disusun

\footnotetext{
H.A.M.J. ten Have, Op.cit, h. 29.
} 
secara koheren menyangkut hakekatAllah dan hubungan-Nya dengan manusia dan alam semesta. Usaha sistematis untuk menyajikan, menafsirkan, dan membenarkan secara konsisten dan berarti, keyakinan akan Allah. ${ }^{10}$ Ketetapan Allah (takdir Allah) atas segala makhluknya yang pasti terjadi dan tidak bisa dihindari oleh manusia jika waktunya telah tiba, akan tetapi dalam menghadapi ketetapan tersebut, manusia masih diberikan kebebasan untuk memilih mana yang terbaik bagi diri mereka.

Oleh karena itu, permasalahan takdir tidak bisa dilepaskan dari ketetapan Allah dan pilihan manusia. Karena dalam melaksanakan ketetapannya, Allah selalu memberikan sebabsebab yang alamiah yang bisa diterima akal manusia, walaupun terkadang tidak sesuai dengan apa yang ada di dalam pikiran dan harapan manusia. Adapun macam-macam takdir, menurut sebagian besar ulama, terbagi dua macam, yaitu: Takdir Mubram dan Takdir Mu'allaq. Takdir mubram adalah ketetapan Allah atas makhluknya yang mana tidak ada kemampuan dari makhluk tersebut untuk menghindarinya. Dalam hal ini, takdir seperti ini lebih sering penulis sebut sebagai Qadha Allah. Artinya, takdir jenis ini adalah kehendak mutlak dari Allah, semua makhluknya suka atau tidak suka harus menerimanya. Contohnya antara lain: kematian, menderita sakit. Sedangkan takdir yang kedua adalah takdir mu'allaq, yaitu ketetapan Allah yang berlaku pada makhluknya sesuai dengan apa yang dilakukannya di dunia sesuai dengan kemampuannya sendiri. Segala ketetapan Allah yang terjadi pada diri manusia sesuai dengan apa yang mereka pilih dalam hidup mereka, segala sesuatu yang terjadi pada diri manusia yang berkaitan dengan masa depan mereka adalah takdir mu'allaq ini. Apa yang sering dipasrahkan oleh mereka adalah takdir yang seperti ini. Contohnya adalah ilmu pengetahuan kedokteran, kemampuan, keahlian (skill) medis, dan sebagainya. ${ }^{11}$

10 Ibid, h. 1090. Gambar etika diunduh dari http:// wordpress.com/2012/10/21/bisnis-dan-etika/,21 Desember 2014.

11 Hasyim, 1983, Umar, Mencari Takdir, Penerbit Ramadhani, Solo, hal. 74
Adapun hadis yang berbicara tentang takdir diantaranya adalah :

Hadis riwayat Turmuzi No. 2294 :

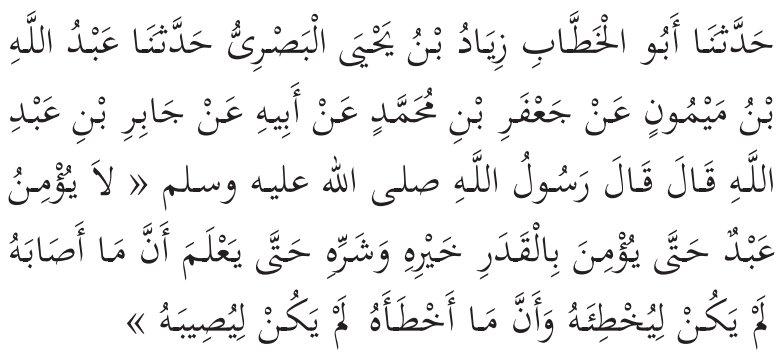

Artinya :

Dari Jabir bin Abdullah berkata : Rasulullah SAW bersabda :"Tidaklah beriman seseorang diantara kamu sebelum ia beriman kepada takdir yang baik dan yang buruk. Sehingga ia mengetahui bahwa apa saja yang ditetapkan akan menimpanya, pasti tidak akan meleset darinya. Dan apa saja yang ditetapkan meleset darinya, pasti tidak akan menimpanya".

Padahal, segala yang terjadi dalam hidup manusia sudah ada jalannya sendiri-sendiri. Hal ini sudah dijelaskan dala Al Qur'an Surah al Hadid ayat 22 :

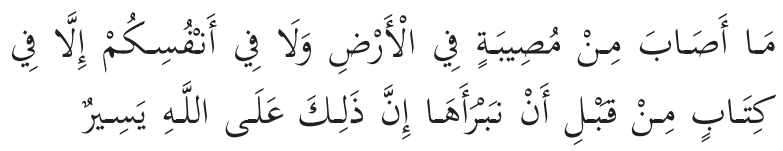

Artinya :

"Tiada suatu bencanapun yang terjadi di bumi dan (tidak pula) pada dirimu sendiri melainkan telah tertulis dalam Kitab (Lauhul Mahfudz) sebelum kami menciptakannya. Sesungguhnya yang demikian itu adalah mudah bagi Allah". Dari uraian di atas dapatlah diambil hikmah bahwasanya takdir tidak hanya sebuah ketetapan yang tidak bisa dirubah. Tetapi takdir adalah kesepakatan bersama antara Allah dan manusia di dalam mengatur kehidupan, kesehatan. Saling memberi dan saling menghargai serta saling mencintai antara satu dengan yang lainnya tentu akan menciptakan hubungan yang harmonis antara 
manusia dan Tuhannya, sehingga takdir yang tadinya menjadi sesuatu yang kelihatan jelek, menjadi suatu nikmat yang didapatkan dari mahklukNya ${ }^{12}$.

\section{Kajian Disiplin IImu Kedokteran.}

Yang dimaksud disiplin kedokteran adalah kepatuhan menerapkan aturan-aturan/ ketentuan penerapan keilmuan kedokteran dalam pelaksanaan pelayanan kedokteran. Lebih khusus, kepatuhan menerapkan kaidahkaidah penatalaksanaan medis (asuhan medis) mencakup antara lain, menegakkan diagnosis, melakukan tindakan pengobatan, dan menetapkan prognosis. Hal tersebut dilakukan dengan menggunakan indikator yang memenuhi standar. Indikator-indikator tersebut meliputi, Standar kompetensi, Standar pelayanan, Standar perilaku etis, Standar asuhan medis, dan Standar klinis. Kongkritnya dokter dalam melaksanakan praktik kedokteran, harus dilakukan sesuai dengan standar pelayanan, standar profesi dan standar prosedur operasional. Hal tersebut dilakukan agar dokter dalam melaksanakan profesinya menerapkan standar-standar yang sudah diatur dalam norma disiplin, sebaliknya apabila dokter tidak melaksanakan standar-standar dalam norma disiplin saat melakukan praktik kedokteran dapat dikategorikan sebagai pelanggaran norma disiplin sebagaimana yang tertuang dalam Pasal 55 UUPK.

\section{Kajian Sengketa Medis/Malpraktik Medis dan Tindak Pidana Oleh Dokter.} Konflik atau sengketa diartikan sebagai ketidaksesuaian paham atas situasi tentang pokok-pokok pikiran tertentu atau karena adanya antagonisme-antagonisme emosional. Konflik juga dapat diartikan sebagai bentuk sublimasi dari logika-logika (mengenai sesuatu hal atau masalah) yang tidak sejalan, berseberangan atau saling bertentangan. Maka berbagai konflik yang melanda dunia kedokteran dan perumahsakitan kita sekarang

12 https://seanochan.wordpress.com/2013/04/19/hadistentang-takdir/. Diakses 18 Agustus 2016. ini tidak harus dipandang sebagai hal yang luar biasa sehingga tidak perlu disikapi secara berlebihan. Dilihat dari sisi positifnya justru konflik atau sengketa dapat meningkatkan kreatifitas, inovasi, intensitas upaya, kohesi kelompok serta mengurangi ketegangan.

Dunia kedokteran dan perumahsakitan juga harus bersikap jujur karena pada kenyataannya masih banyak kelemahan dan kekurangan dalam melaksanakan tatakelola klinik yang baik (good clinical governance), disamping belum secara sempurna mampu memenuhi prinsipprinsip dalam merancang sistem pelayanan kesehatan yang lebih aman (safer health care system) guna mencegah atau setidaktidaknya mengurangi terjadinya adverse events (kejadian yang tidak diharapkan). Dokter adalah bagian dari masyarakat, dan sebagai anggota masyarakat mereka dapat melakukan tindak pidana biasa (everyday crime); seperti mencuri, menipu, menganiaya, memperkosa dan lain sebagainya. Selain itu dokter juga sebagai professional (pemangku amalan perobatan) sehingga mereka dapat pula melakukan tindak pidana sudah dalam konteks hubungan dokter-pasien dalam bidang kedokteran atau seputar pelaksanaan tindakan kedokteran (medico crime), yang terdiri dari:

a) Medico-patient crime (tindak pidana yang dilakukan terhadap pasiennya, contoh: mengambil handphone ketika pasiennya sedang tidur) dan

b) Medico-professional crime (tindak pidana dengan menggunakan ilmu dan ketrampilan medisnya, seperti euthanasia atau melakukan tindakan medis yang tidak berdasarkan medical indication demi mendapatkan uang lebih banyak). ${ }^{13}$

5. Kajian Perlindungan Hukum Profesi Dokter.

Menurut Mochtar Kusumaatmadja, Pengertian hukum yang memadai harus tidak hanya memandang hukum itu sebagai

13 Garwood-Gowers, A, Wheat, K, Tingle, J, 2005., Contemporary Issues in Healthcare Law and Ethics, Reed Elsevier 
suatu perangkat kaidah dan asas-asas yang mengatur kehidupan manusia dalam masyarakat, tapi harus pula mencakup lembaga (institusi) dan proses yang diperlukan untuk mewujudkan hukum itu dalam kenyataan. ${ }^{14}$ Pengertian perlindungan hukum adalah suatu perlindungan yang diberikan terhadap subyek hukum dalam bentuk perangkat hukum baik yang bersifat preventif maupun yang bersifat represif, baik yang tertulis maupun tidak tertulis. Dengan kata lain perlindungan hukum sebagai suatu gambaran dari fungsi hukum., yaitu konsep dimana hukum dapat memberikan suatu keadilan, ketertiban, kepastian, kemanfaatan dan kedamaian. ${ }^{15}$

Dalam pandangan Philipus M. Hadjon, konteks negarahukum Indonesiayang dijadikan dasar untuk membangun landasan bernegara berdasarkan Pancasila haruslah memberikan perlindungan hukum terhadap warga negara masyarakatnya sesuai dengan nilai-nilai Pancasila. Perlindungan hukum berdasarkan Pancasila merefleksikan pengakuan dan perlindungan hukum terhadap harkat dan martabat manusia atas dasar nilai Ketuhanan Yang Maha Esa, Kemanusiaan, Persatuan, Permusyawarakatan dan Keadilan sosial. Nilai-nilai Pancasila melahirkan pengakuan dan perlindungan hak asasi manusia dalam wadah negara kesatuan yang menjunjung tinggi semangat kekeluargaan dalam mencapai kesejahteraan bersama. Oleh sebab itu, hal penting yang perlu dikemukakan yaitu asas kerukunan berdasarkan kekeluargaan. ${ }^{16} \mathrm{Jadi}$, perlindungan hukum berawal dari kepentingan atas penghargaan terhadap individu agar supaya tidak dilanggar hak dan kewajibannya. Dalam konteks ke Indonesiaan, perlindungan individu adalah pengakuan dan perlindungan hak asasi yang berdasarkan pada nilai-nilai Pancasila.

14 Badan Pembinaan Hukum Nasional, 2011, Pengkajian Hukum Tentang Perlindungan Hukum Bagi Upaya Menjamin Kerukunan Umat Beragama, Kementerian Hukum Dan Hak Asasi Manusia, Jakarta, h. 15.

15 Ibid.

16 Hadjon P. M. , 1987, Perlindungan Hukum Bagi Rakyat di Indonesia, Bina IImu, Surabaya,h. 84.
Pasal 45 Undang-Undang Rumah Sakit ayat (1) menjelaskan bahwa pasien berhak menolak atau menghentikan pengobatan. Pasien yang menolak pengobatan karena alasan finansial harus diberikan penjelasan bahwa pasien berhak memperoleh jaminan dari pemerintah.

Atas dasar ketentuan tersebut dapat diuraikan bahwa, perlindungan hukum bagi Rumah Sakit (dokter) merupakan hak bagi Rumah Sakit dalam kedudukan hukumnya sebagai subyek hukum (recht persoon), yang melakukan hubungan hukum dengan pihak lain, yaitu pasien. Sebagai salah satu fasilitas pelayanan kesehatan yang tugas pokoknya melayani masyarakat dalam lingkungan hukum publik, yang artinya pula membantu pemerintah dalam pelayanan publik, maka sudah selayaknya Rumah Sakit/ dokter mendapatkan perlindungan hukum.

\section{Kajian Perlindungan Hukum Berbasis Nilai Keadilan.}

Profesi kedokteran atau profesi dokter merupakan sebuah profesi yang luhur (noble profession), yang dalam pengabdiannya lebih mengutamakan kepentingan orang lain dan masyarakat (altruistic). Oleh sebab itu menganjurkan agar profesi yang luhur tersebut dipercayakan hanya kepada orang-orang yang sopan, terhormat, dan memiliki jiwa paternalistik. Profesi itu sendiri, ${ }^{17}$ merupakan sebuah pekerjaan yang dicirikan memiliki Knowledge, Cleverness, Devotion; dan Purity (physic and mind).

Knowledge merupakan ciri terpenting dari profesi disebabkan knowledge inilah yang akan membimbing profesional di bidang kesehatan (seperti: dokter, dokter gigi, perawat, dan bidan) menuju ke suatu tingkat kompetensi dan norma tertentu sehingga mereka mampu melaksanakan tugas dan pengabdiannya dengan benar. Sudah barang tentu knowledge yang dipersyaratkan pada zaman Charaka Samhita adalah pengetahuan tentang tetumbuhan (herbal) yang berkhasiat

17 Jonsen, A, R, Siegler, M, Winslade, W, J, 2006, CInical Ethics, A Practical Approach to Ethical Decision in Clinical Medicine, McGraw-Hill Medical Publishing Division, New York, h. 1-11. 
sebagai obat. Cleverness merupakan ciri penting lainnya dari profesi di bidang amalan perobatan sebab dalam mengatasi berbagai macam problem kesehatan diperlukan kecerdasan, ketrampilan, dan kecekatan. Devotion juga merupakan ciri profesi yang tidak kalah penting, dan ia diperlukan sebab dengan jiwa pengabdian yang tulus atas dasar kemanusiaan maka para profesional di bidang amalan perobatan akan memperoleh arahan dalam melaksanakan pengabdiannya. Purity (physic and mind) merupakan ciri terakhir yang diperlukan dalam profesi di bidang amalan perobatan sebab dengan penampilan fisik yang bersih (yang melambangkan kesucian) disertai pikiran yang jernih pula maka pasien dan masyarakat akan menaruh kepercayaan.

Profesi mensyaratkan adanya kompetensi ("the condition of being capable" atau "the capacity to perform task and role") agar pemangku profesi dapat melaksanakan peran, tugas, dan tanggungjawabnya dengan baik dan benar. Dalam kaitannya dengan profesi di bidang amalan perobatan maka kompetensi mutlak dipersyaratkan disebabkan profesi di bidang ini bukan merupakan hak alami (natural right) yang boleh diamalkan oleh siapa saja. Hak melakukan amalan perobatan lebih merupakan hak istimewa (privilege) yang diberikan hanya kepada seseorang karena kompetensinya. Guna menjamin agar para profesional lebih mematuhi nilai dan norma dalam etika maka tradisi yang telah dirintis oleh pengikut Pythagoras perlu dilestarikan dengan mewajibkan kepada setiap lulusan dokter untuk mengucapkan sumpah atau janji manakala ingin menjadi profesional (pengemban profesi amalan perobatan). Sumpah profesi (seperti Sumpah Dokter, Sumpah Perawat, atau Sumpah Bidan) pada hakekatnya merupakan janji kepada masyarakat (social contract) yang diucapkan atas nama Tuhan Yang Maha Esa, sehingga konsekuensinya wajib dilaksanakan guna menjaga hubungan baik dengan masyarakat (habblum minan naas) dan hubungan dengan Sang Pencipta (habblum minal Allah).
Perlindungan hukum profesi dokter dalam penyelesaian sengketa medis menurut Sila Ke 4 dan Ke 5 Pancasila; dan menurut Pasal 28 G dan Pasal 28 H UUD Negara Republik Indonesia 1945 merupakan penjabaran dari HAM. Hak Asasi Manusia adalah seperangkat hak yang melekat pada hakikat dan keberadaan manusia sebagai makhluk Tuhan Yang Maha Esa dan merupakan anugerah-Nya yang wajib dihormati, dijunjung tinggi dan dilindungi oleh negara, hukum, dan setiap orang demi kehormatan pemerintah serta perlindungan harkat dan martabat manusia sebagaimana didapat dalam Pasal 1 angka 1 UU No. 39 Tahun 1999 tentang Hak Asasi Manusia. Kesehatan adalah Hak Asasi Manusia (HAM) yang fundamental dan tak ternilai demi terlaksananya HAM yang lain menurut Komentar Umum No. 14 Komite Ekonomi Sosial Budaya PBB). Dijelaskan juga pada Pasal 25 ayat (1) Deklarasi Universal HAM bahwa setiap manusia mempunyai hak atas standar kehidupan yang cukup bagi kesehatan dirinya dan keluarganya, yang mencakup makanan, tempat tinggal, pakaian dan pelayanan kesehatan serta pelayanan sosial yang penting.

Perlindungan hukum profesi dokter dalam penyelesaian sengketa medis di dalam silasila Pancasila dapat dilihat dalam uraian butir-butir Pancasila yang terdiri dari 45 butir sebagaimana ditetapkan dalam Tap MPR No. I/MPR/2003. Uraian perlindungan hukum terdapat dalam uraian butir Pancasila sila ke 4 dan ke 5 , serta pasal $28 \mathrm{G}$ dan $28 \mathrm{H}$ UUD Negara Republik Indonesia 1945 dapat dijelaskan sebagai berikut:

a. Sila ke-empat: Kerakyatan yang dipimpin oleh hikmat kebijaksanaan dalam permusyawaratan/perwakilan. Butir-butirnya terdiri dari:

1. Sebagai warga negara dan warga masyarakat, setiap manusia Indonesia mempunyai kedudukan, hak, dan kewajiban yang sama.

2. Tidak boleh memaksakan kehendak kepada orang lain. 
3. Mengutamakan musyawarah dalam mengambil keputusan untuk kepentingan bersama.

4. Musyawarah untuk mencapai mufakat diliputi oleh semangat kekeluargaan.

5. Menghormati dan menjunjung tinggi setiap keputusan yang dicapai sebagai hasil musyawarah.

6. Dengan iktikad baik dan rasa tanggung jawab menerima dan melaksanakan hasil keputusan musyawarah.

7. Didalam musyawarah diutamakan kepentingan bersama di atas kepentingan pribadi dan golongan.

8. Musyawarah dilakukan dengan akal sehat dan sesuai dengan hati nurani yang luhur.

9. Keputusan yang diambil harus dapat dipertanggungjawabkan secara moral kepada Tuhan Yang Maha Esa, menjunjung tinggi harkat dan martabat manusia, nilai-nilai kebenaran dan keadilan mengutamakan persatuan dan kesatuan demi kepentingan bersama.

10. Memberikan kepercayaan kepada wakil-wakil yang dipercayai untuk melaksanakan permusyawaratan.

b. Sila ke-lima: Keadilan sosial bagi seluruh rakyat Indonesia. Butirbutirnya terdiri dari:

1. Mengembangkan perbuatan yang luhur, yang mencerminkan sikap dan suasana kekeluargaan dan kegotongroyongan.

2. Mengembangkan sikap adil terhadap sesama.

3. Menjaga keseimbangan antara hak dan kewajiban.

4. Menghormati hak orang lain.

5. Suka memberi pertolongan kepada orang lain agar dapat berdiri sendiri.

6. Tidak menggunakan hak milik untuk usaha-usaha yang bersifat pemerasan terhadap orang lain.
7. Tidak menggunakan hak milik untuk hal-hal yang bersifat pemborosan dan gaya hidup mewah.

8. Tidak menggunakan hak milik untuk bertentangan dengan atau merugikan kepentingan umum.

9. Suka bekerja keras.

10. Suka menghargai hasil karya orang lain yang bermanfaat bagi kemajuan dan kesejahteraan bersama.

11. Suka melakukan kegiatan dalam rangka mewujudkan kemajuan yang merata dan berkeadilan sosial.

c. Pasal 28G ayat (1) UUD Negara Republik Indonesia Tahun 1945: Setiap orang berhak atas perlindungan diri pribadi, keluarga, kehormatan, martabat, dan harta benda yang di bawah kekuasaannya, serta berhak atas rasa aman dan perlindungan dari ancaman ketakutan untuk berbuat atau tidak berbuat sesuatu yang merupakan hak asasi.

d. Pasal 28H ayat (1) UUD Negara Republik Indonesia Tahun 1945: Setiap orang berhak hidup sejahtera lahir dan batin, bertempat tinggal, dan mendapatkan lingkungan hidup yang baik dan sehat serta berhak memperoleh layanan kesehatan.

\section{Kelemahan-kelemahan dalam Undang- Undang Praktik Kedokteran dan Sikap Menghadapi Undang-Undang Praktik Kedokteran.}

Tanpa mengurangi sedikitpun rasa hormat atas jerih payah semua pihak yang terlibat dalam penyusunan dan pengesahan UU Praktik Kedokteran, dengan jujur dari berbagai kajian baik dari tinjauan pustaka, perbandingan hukum dan wawancara dari berbagai sumber dapat katakan bahwa ada beberapa kekurangan dan kesalahan yang terdapat dalam UU Praktik Kedokteran. Pada 
UU praktik kedokteran materi didalamnya terlalu teknis,

Memang tidak bisa disalahkan jika maunya lembaga legislatif membuat undang-undang seperti itu, akan tetapi harus disadari bahwa undang-undang yang terlalu teknis akan menyebabkan undang-undang itu menjadi rigid dan rentan terhadap perubahan tidak prinsipiel sehingga akibatnya tidak akan tahan lama.

Satu hal lagi yang perlu difahamkan kepada semua pihak adalah, dengan diundangkannya UU Praktik Kedokteran maka hal ini sebenarnya merupakan preseden buruk mengingat ide ketika UU Kesehatan dirancang adalah untuk menyatukan berbagai aturan di bidang kesehatan yang tersebar (diversifikasi) di berbagai produk perundangundangan (antara lain UU Tentang PokokPokok Kesehatan, UU Tenaga Kesehatan, UU Kesehatan Jiwa, UU Farmasi, UU Kesehatan Kerja, UU Higiene dan Sanitasi, UU Wabah dan masih banyak lagi). Mestinya tentang praktik kedokteran (juga tentang Sarana Kesehatan termasuk rumah sakit) diatur saja dalam Peraturan Pemerintah sebagaimana diamanatkan oleh UU Kesehatan. Dengan diundangkannya UU Praktik Kedokteran (dan juga UU Rumah Sakit) maka apa yang sudah berhasil disatukan kedalam UU Kesehatan, dipecah-pecah kembali seperti sediakala.

Rumusan definisi praktik kedokteran tidak menggambarkan "pekerjaan perobatan" dalam perspektif luas sebagaimana dimaksud dalam UU Kesehatan (yaitu boleh menggunakan ilmu kedokteran atau menggunakan cara lain yang bertanggungjawab), berdasarkan Pasal 1 ayat (1) UU Praktik Kedokteran "Praktik kedokteran adalah rangkaian kegiatan yang dilakukan oleh dokter atau dokter gigi terhadap pasien dalam melaksanakan upaya kesehatan". Walaupun penulis sadar benar bahwa suatu definisi yuridis memang dapat dirumuskan dalam berbagai versi sesuai perspektif pembuat definisi dalam hal ini adalah lembaga legislatif. Hanya saja definisi yuridis Praktik Kedokteran sebagaimana dirumuskan dalam UU Praktik Kedokteran memiliki konsekuensi hukum yang jauh berbeda dengan definisi yuridis dari kebanyakan negara-negara lain.

Di Florida contohnya, praktik kedokteran (medical practice) didefinisikan sebagai berikut:

"Any person .... shall be deemed to be practicing medicine .... who holds himself out as being able to diagnose, treat, operate or prescribe for any human disease, pain, injury, deformity or physical condition, or who shall offer or undertake by any means or methods, to diagnose, treat, operate or prescribe for any human disease, pain, injury, deformity or physical condition.

(The exclusions usually refer to type of activities, such as the administration of home remedies, treatment by prayer or spiritual means).

Dengan definisi seperti tersebut diatas maka siapapun (any person) yang melakukan pekerjaan yang mengandung essensi mengobati orang sakit maka ia, di Negara bagian Amerika tersebut, dapat dikatagorikan melakukan praktik kedokteran (medical practice) walaupun mereka bukan seorang dokter ataupun dokter gigi. Tentunya hal semacam ini tidak berlaku disini karena definisi yuridis praktik kedokteran di negara kita sudah dibatasi hanya apabila yang melakukan rangkaian kegiatan pengobatan adalah dokter atau dokter gigi.

Sebagaimana diketahui bahwa dari Pasal 56 dan Pasal 59 UU Kesehatan dapat disimpulkan bahwa SIP (Surat Izin Praktik) merupakan ijin sarana kesehatanswastatak berbadan hukum yang diselenggarakan oleh dokter atau dokter gigi, tetapi kenapa UU Praktik Kedokteran masih mensyaratkan SIP (disamping Surat Tanda Registrasi) bagi dokter yang kerja di rumah sakit, sehingga seolah-olah SIP merupakan lisensi.

Perlu diluruskan kembali pemahaman kita, bahwa Lisensi merupakan personal privilege yang memberikan kewenangan melakukan suatu jenis amalan (yang biasanya dapat membahayakan apabila dilakukan oleh seseorang yang tidak mempunyai kompetensi). Kebijakan bahwa dokter harus memiliki lisensi merupakan kebijakan untuk 
melindungi kepentingan masyarakat, sehingga oleh karenanya merupakan ranah (subject matter) dari hukum publik. Adapun hakekat dari lisensi adalah merupakan dokumen yang merubah status hukum orang biasa yang tidak memiliki privilige (hak istimewa) menjadi seseorang yang memiliki privilege. Berdasarkan Pasal 29 ayat (3) dan Pasal 35 UU Praktik Kedokteran, lisensi dokter adalah Surat Tanda Registrasi (STR).

Sementara SIP Dokter atau SIP Dokter Gigi merupakan surat ijin sarana kesehatan (lihat Pasal 56 dan Pasal 59 UU Kesehatan), sehingga hakekatnya, SIP merupakan dokumen yang merubah status hukum rumah biasa menjadi "sarana kesehatan". Kebijakan bahwa sarana kesehatan tak berbadan hukum yang diselenggarakan oleh dokter atau dokter gigi harus memiliki ijin merupakan subject matter dari hukum publik guna melindungi kepentingan masyarakat dari sarana kesehatan yang tak memenuhi syarat.

Pemberian kewenangan regeling (membuat aturan) kepada lembaga independen seperti Konsil Kedokteran Indonesia, dapat menimbulkan keadaan dimana produk regeling tidak dapat lagi dikontrol oleh undang-undang. Mestinya untuk Konsil Kedokteran Indonesia dibuatkan peraturan tersendiri oleh institusi yang sepantasnya diserahi kewenangan mengatur, sementara konsil hanyalah melaksanakan misinya sesuai peraturan tersebut.

Jika UU Praktik Kedokteran (juga UU Kesehatan) menyatakan bahwa orang yang hendak melakukan praktik pengobatan berlandaskan ilmu kedokteran harus memiliki kewenangan (baca: Lisensi atau STR) maka sebenarnya hal itu merupakan subject matter dari hukum publik karena ada kepentingan publik yang perlu dilindungi dari pengobat yang tak berkompeten. Tetapi jika dokter sudah memiliki kewenangan (baca: Lisensi atau STR) dan bermaksud bekerja sebagai professional (fungsional) di salah satu rumah sakit maka mestinya tidak perlu lagi meminta ijin kepada otoritas kesehatan daerah (public bureaucrat) dalam bentuk SIP mengingat masalah hubungan antara dokter dan rumah sakit merupakan subject matter dari hukum privat. Apalagi menurut UU Kesehatan, SIP merupakan "ijin sarana kesehatan tak berbadan hukum yang diselenggarakan swasta" (dalam hal ini oleh dokter di rumahnya).

Bahwa setiap sarana kesehatan (Rumah Sakit, Puskesmas atau Praktik Dokter di rumahnya) harus memiliki ijin maka hal itu juga merupakan ranah hukum publik karena untuk melindungi masyarakat dari sarana kesehatan yang tak memenuhi syarat. Lalu apa pertimbanganya sehingga untuk bekerja di rumah sakit yang sudah berijin harus membawa-bawa surat ijin sarana kesehatan pribadi? Jika tujuan dan konteksnya untuk mengontrol agar dokter tidak menggunakan lisensinya (baca: STR) untuk bekerja rangkap melebihi batas jumlah sarana kesehatan yang dibolehkan maka hal itu sebetulnya dapat ditindaklanjuti dengan menerapkan sistem pelaporan; yaitu mewajibkan dokter bekerja di sarana kesehatan maupun sarana kesehatan yang ketempatan dokter untuk melapor kepada otoritas kesehatan daerah.

Sekarang semuanya terpulangkan kepada Menteri Kesehatan yang oleh UU Praktik Kedokteran diberi kewenangan membuat peraturan mendapatkan SIP dan Konsil Kedokteran Indonesia yang oleh UU Praktik Kedokteran diberi kewenangan regeling tentang lisensi. Bahwa pada abad 18 George Barkeley sudah mengatakan dan menyadarkan kepada kita tentang pentingnya memahami makna: "Jangan mengaburkan kata dan bahasa karena hal itu akan sama artinya dengan meniup debu di depan mata sehingga di kemudian hari tidak akan dapat melihat sesuatu dengan jelas". Apa yang terjadi sekarang ini adalah persis seperti apa yang dikatakan oleh filosof tersebut. Kini kita tidak bisa lagi melihat dengan jelas apa bedanya lisensi dengan surat ijin praktik. Dan hal itu dimulai sejak sebutan lisenai dokter dirubah dari SID (Surat ljin Dokter) menjadi SP (Surat Penugasan). Maka dalam rangka menyusun peraturan tentang SIP oleh Menteri Kesehatan dan 
peraturan tentang STR oleh Konsil sebagai tindak lanjut dari UU Praktik Kedokteran, kedua institusi tersebut perlu meluruskan lebih dahulu konsep yang selama ini kabur dengan menafsirkan UUPK secara cerdas dan cermat tanpa menafikan UU Kesehatan agar para dokter terhindar dari kebingungan dan birokrasi yang berlebihan.

Berkenaan dengan penggunaan lisensi (STR) untuk bekerja di banyak sarana kesehatan (RS) maka sudah sepantasnya dibatasi jumlahnya demi mutu dan safety. Pengawasannya dapat dilakukan oleh otoritas kesehatan daerah, tetapi bentuk pengawasannya cukup dengan menetapkan kewajiban kepada dokter maupun sarana kesehatan yang ketempatan untuk melapor.

Sebagaimana diketahui bahwa untuk tindak pidana diluar KUHPidana berlaku pula ketentuan umum yang terdapat dalam KUHPidana. Mengingat konsekuensi yuridis materiel (antara lain percobaan, penyertaan atau bentuk pidananya) dan konsekuensi yuridis formil (antara lain soal penahanan atau habisnya tenggang waktu penuntutan dan pelaksanaan eksekusi) berbeda antara "kejahatan" (fundamentally wrong) dan "pelanggaran" (legally wrong) maka seharusnya setiap tindak pidana dalam UU Praktik Kedokteran dikualifikasi sebagaimana halnya tindak pidana yang dapat kita lihat dalam UU Kesehatan. Karena tidak dikualifikasi maka hakim harus bekerja keras membuat interpretasi sendiri mengenai kualifikasinya dan tentunya hal ini akan membuka peluang terjadinya interpretasi yang berbeda-beda untuk kasus yang sama. Penyidik perkara juga bisa salah dalam menerapkan hukum formil (KUHAP) akibat ketidakjelasan mengenai jenis perkara yang sedang ditanganinya.

Selain tidak disebut kualifikasinya, sanksinyapun menurut pendapat penulis amat memberatkan para dokter dan dokter gigi. Dan beratnya hukuman tersebut mengingatkan kepada kedokteran di era Priestly Medicine (Mesir kuno dan Babilonia), yaitu hukuman potong tangan.

Undang-Undang Praktik Kedokteran dibuat karena ada kebutuhan masyarakat akan undang-undang yang berkaitan dengan upaya di bidang kesehatan. Mengingat masyarakat itu sendiri terdiri dari berbagai macam golongan dan subsistem dengan hak dan kepentingannya masing-masing yang sering kali tidak searah atau bahkan saling bertentangan satu sama lain maka undang-undang (yang merupakan produk legislatif) harus berupaya mengadopsi kompromi-kompromi. Adanya maksim dalam sosiologi hukum yang menyatakan bahwa "tidak ada satupun undang-undang yang tidak cacat sejak dilahirkan" merupakan maksim yang cukup rasional. Oleh sebab itu jika kita mengharapkan setiap undang-undang harus sempurna tanpa cacat, barangkali kita tidak akan pernah memiliki undang-undang di bidang apapun.

Menurut Satjipto Rahardjo, guru besar sosiologi hukum Undip, bahwa kita tidak bisa menyerahkan begitu saja perjalanan selanjutnya suatu undangundang (termasuk UU Praktik Kedokteran) hanya kepada hukum, apalagi hukum yang dijalankan secara normatif-dogmatis. Sebagai stakeholder yang berkepentingan, publik dan masyarakat bisa turut menjaga agar hukum yang cacat itu masih bisa diupayakan untuk berprestasi positif. Sejalan dengan apa yang dikatakan Holme (the life of the law has not been logic, but experience) dan apa yang dikatakan Karl Renner (the development of the law works out what is socially reasonable) maka debat tentang UU Praktik Kedokteran harus ditindaklanjuti dengan upaya agar UU Praktik Kedokteran bisa lebih memberikan rasa keadilan kepada masyarakat luas.

Memang tidak ada salahnya samasekali jika timbul pemikiran untuk mengajukan UU Praktik Kedokteran ke Mahkmah Konstitusi guna diuji materinya (judicial review). Hanya saja yang perlu dipertimbangkan adalah bahwa sampai sekarang ini tidak kurang dari 50 buah undang-undang sudah didaftarkan untuk diuji materi. Selain itu, Mahkamah Konstitusi tidak berwenang memperbaiki undang-undang. Andaikata mahkamah memutuskan bahwa UU Praktik Kedokteran atau beberapa 
pasal dari UU Praktik Kedokteran tidak lagi mempunyai kekuatan mengikat sebagai UU, maka perbaikan selanjutnya tetap menjadi kewenangan lembaga legislatif. Oleh sebab itu jalan terbaik yang harus ditempuh dalam rangka mensikapi UU Praktik Kedokteran adalah mengikuti lebih dahulu saran Satjipto Rahardjo, baru kemudian melobi lembaga legislatif agar dalam waktu yang tidak terlalu lama bersedia merevisi UU Praktik Kedokteran.

\section{Rekonstruksi Perlindungan Hukum Profesi Dokter.}

Dari uraian dan analisis di atas penulis menyusun suatu rekonstruksi perlindungan hukum profesi dokter dalam penyelesaian sengketa medis antara dokter dan pasien yang berbasis nilai keadilan, berdasarkan hasil dari wawancara mendalam dari berbagai narasumber, observasi di lapangan tentang kasus dugaan malpraktik dan penerapan perundang-undangan yang berlaku ${ }^{18}$ didapati

18 Wawancara dengan Kompol Suwarto, permasalahnnya dokter anastesinya kurang atau tidak ada, jadi dokter anastesinya itu mengambil dari rumah sakit lain, hanya datang sebentar kemudian memberikan resep untuk dilakukan tapi ditinggal lagi karena praktik di tempat lain lagi padahal ini belum selesai, harusnya ditunggu sampai pasien benarbenar dinyatakan sadar kembali. Waktu itu saya benar-benar tanya tentang dokter anastesinya, kalau tidak salah waktu itu dokter anestesinya dari Tegal. Sanksi pidana atau perdata yang muncul Penyidik itu tidak punya kewenangan untuk menilai undangundang, artinya sanksinya itu berat atau tidak berat Penyidik itu tidak punya kewenangan untuk menilai karena yang membuat undang-undang adalah lembaga yudikatif, pemerintah, dan DPR. Penyidik atau polisi hanya menjalankan undang-undang, undang-undangnya seperti itu dijalankan nanti jaksa menuntut, hakim memvonis, jadi kita tidak punya kewenangan untuk itu. Banyak undang-undang di tempat kita yang aturan hukumnya kadang-kadang tidak sesuai mungkin mencuri ayam ancaman hukumannya sama seperti mencuri motor atau mencuri mobil, itu karena bunyinya seperti itu. Sama ancaman hukumannya yang di undang-undang praktik kedokteran itu kan terlalu berat atau terlalu ringan, termasuk berat itu ancaman hukumannya tapi kita tidak punya kewenangan untuk menilai itu. Wawancara dengan dr. Widodo Yulianto, Mkes, peraturan perundangan sudah baik, namun di lapangan norma etik, norma disiplin dan norma hukum dilaksanakan bersamaan, tidak bisa hanya satu norma saja. Ini menyebabkan pemahaman masing-masing dokter berbeda. Menejemen harus bahwa kajian perundang-undangan yang berlaku dalam praktik kedokteran yaitu norma etik, norma disiplin ilmu kedokteran dan norma hukum. Perbandingan kasus dan penyelesaian secara hukum di negara lain: Malaysia dan Singapura serta studi kasuskasus malpraktik di Amerika Serikat dan Israel. Dalam hukum tersebut, pidana terhadap dokter hanya diberlakukan untuk perbuatan yang bersifat kesengajaan (intentional tort) disebabkan adanya hubungan profesional (professional relationship) antara dokter dan pasien. Meski demikian, pasien tetap dapat menggugat dokter membayar ganti rugi dalam rangka pemulihan hak atas kelalaian yang telah dilakukan dokter.

Melalui Teori-teori dalam grand theory, middle theory dan applied theory, Dapat dilakukan 2 rekonstruksi, yaitu:

a) Rekontruksi Nilai:

Menurut Teori Stufenbau adalah teori mengenai sistem hukum oleh Hans Kelsen yang menyatakan bahwa sistem hukum merupakan sistem anak tangga dengan kaidah berjenjang dimana norma hukum yang paling rendah harus berpegangan pada norma hukum yang lebih tinggi, dan kaidah hukum yang tertinggi (seperti konstitusi) harus berpegangan pada norma hukum yang paling mendasar (grundnorm). Menurut Kelsen norma hukum yang paling dasar (grundnorm) bentuknya tidak kongkrit (abstrak). Contoh norma hukum paling dasar abstrak adalah Pancasila.

Teori Hans Kelsen yang mendapat banyak perhatian adalah hierarki

selalu mengingatkan. Di lapangan aplikasi ke 3 norma antar dokterpun berbeda (senior-yunior). Rumah sakit yang sudah terakredisi ada ketentuan yang ada di borang untuk melaksanakan standarstandar, dokter dibatasi kewenangan kliniknya berdasarkan kredensial dari komite medis, ini salah satu perlindungan dokter dan pasien. Di dalam Undang-Undang jelas ada keseimbangan/keadilan setiap perlindungan dokter juga perlindungan pasien. Karena ada perbedaan, proses hukum sengat panjang, melelahkan dan tidak produktif walaupun kami (dokter) memenangkan proses hukum, ke depan sebaiknya diselesaikan oleh peradilan cepat dan efisien. 
norma hukum dan rantai validitas yang membentuk piramida hukum (stufen theorie). Salah seorang tokoh yang mengembangkan teori tersebut adalah murid Hans Kelsen, yaitu Hans Nawiasky. Teori Nawiasky disebut dengan theorie von stufenufbau der rechtsordnung. Susunan norma menurut teori tersebut antara lain, Norma fundamental negara (Staats fundamental norm), Aturan dasar negara (staats grundgesetz), Undangundang formal (formell gesetz),

Peraturan pelaksanaan dan peraturan otonom (verordnung en autonome satzung). Staats fundamental norm adalah norma yang merupakan dasar bagi pembentukan konstitusi atau Undang-Undang Dasar (staats verfassung) dari suatu negara. Posisi hukum dari suatu Staats fundamental norm adalah sebagai syarat bagi berlakunya suatu konstitusi. Staats fundamental norm ada terlebih dahulu dari konstitusi suatu negara.

Menurut Nawiasky, norma tertinggi yang oleh Kelsen disebut sebagai norma dasar (basic norm) dalam suatu negarasebaiknyatidak disebutsebagai staats grundnorm melainkan Staats fundamental norm, atau norma fundamental negara. Grundnorm pada dasarnya tidak berubah-ubah, sedangkan norma tertinggi berubah misalnya dengan cara kudeta atau revolusi. Teoritangga menggambarkan dasar berlakunya suatu kaidah terletak pada kaidah yang diatasnya. Menurut Kelsen: Legalitas Peraturan terletak pada UU, dan legalitas UU terletak pada UUD. ${ }^{19}$

Dengan landasan teori Hans Kelsen dan penguatan pemahaman humanistic quality perilaku etis profesional, sesuai dengan prinsip filsafati, disiplin keilmuan, dan aturan etis profesi. Dengan demikian pelanggaran dokter dalam melakukan praktik kedokteran dapat dikategorikan sebagai "Teori harmonisasi antara norma etik, norma disiplin ilmu kedokteran dan norma hukum", maksudnya dalam praktik kedokteran ke tiga norma tersebut merupakan satu kesatuan yang utuh yang harus dilaksanakan oleh pemberi layanan kedokteran, apabila terjadi pelanggaran maka dapat digambarkan sebagai piramida seperti pada Gambar 1. Apabila pelanggaran terjadi dikarenakan melanggar fundamental ethical principles atau Hak Asasi Manusia yaitu perilaku spesifik profesional yang hampir dipastikan mendekati benar atau mendekati salah dalam praktik kedokteran. Penulis kategorikan sebagai Ethico-Medico-Legal seperti pada Gambar 2.

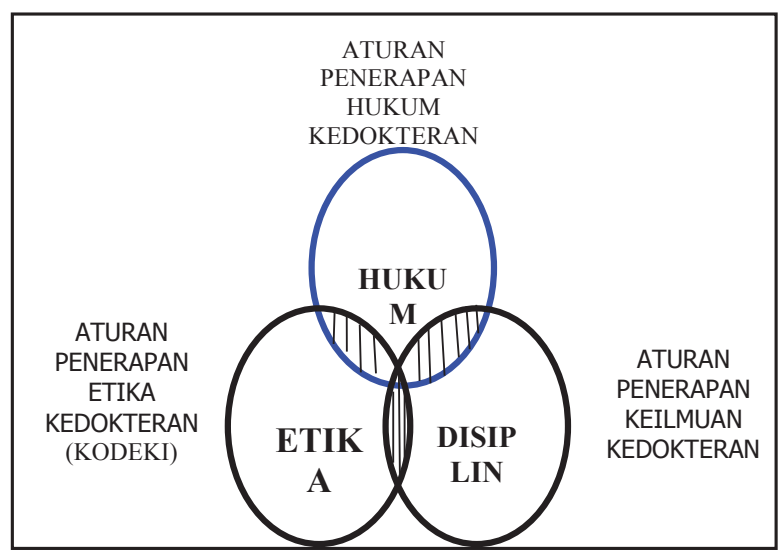

Gambar 1.

Teori Harmonisasi Ethico-Medico-Legal

19 Hans Kelsen, 2010, "Teori hukum murni-dasasrdasar ilmu hukum normative" terjemahan The fure of teory : Barkely University of California press :1978 : Nusa Media, Bandung. 


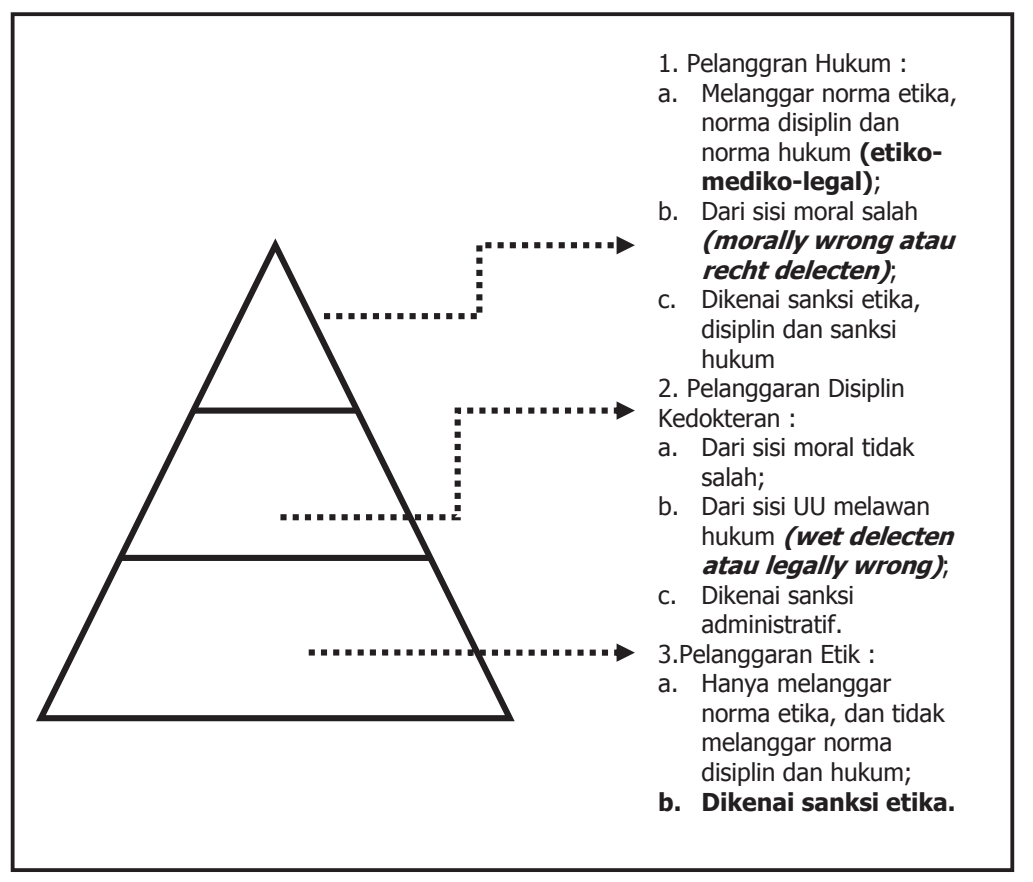

Gambar 2.

\section{Algoritma Pelanggaran Ethico-Medico-Legal}

b) Rekonstruksi Hukum.

Rekonstruksi beberapa Pasal

Undang-Undang Nomor 29 Tahun

2004 tentang Praktik Kedokteran :

Pasal 1 ayat (1), Pasal 50 huruf a dan b, Pasal 75, Pasal 76, Pasal 77, Pasal 79.
Dari uraian diatas kesimpulan rekonstruksi perlindungan hukum profesi dokter dalam sengketa medis antara dokter dan pasien yang berbasis nilai keadilan adalah seperti pada Tabel 1.

Tabel 1

Rekonstruksi hukum Pasal 1 ayat (1), Pasal 50 huruf a dan b, Pasal 75 ayat (1), Pasal 76, Pasal 79 UUPK

\begin{tabular}{|c|l|l|l|}
\hline No & Sebelum Rekonstruksi & Kelemahan-kelemahan & Hasil Rekonstruksi \\
\hline 1 & $\begin{array}{l}\text { Pasal 1 ayat (1) } \\
\text { Praktik kedokteran adalah rangkaian } \\
\text { kegiatan yang dilakukan oleh } \\
\text { dokter dan dokter gigi terhadap } \\
\text { pasien dalam melaksanakan upaya } \\
\text { kesehatan. }\end{array}$ & $\begin{array}{l}\text { Definisinya terlalu } \\
\text { umum, tidak ada } \\
\text { kewenangan kliniknya. }\end{array}$ & $\begin{array}{l}\text { Pasal 1 ayat (1) } \\
\text { Praktik kedokteran adalah } \\
\text { rangkaian kegiatan yang } \\
\text { meliputi: } \\
\text { a. upaya kesehatan } \\
\text { perorangan: diagnosis, terapi, } \\
\text { tindakan medis, memberi } \\
\text { obat pada setiap orang } \\
\text { yang menderita sakit, nyeri, } \\
\text { gangguan psikis atau setiap } \\
\text { orang yang mengupayakan } \\
\text { diagnosis, terapi, memberi } \\
\text { obat setiap orang sakit, nyeri, } \\
\text { gangguan psikis. } \\
\text { b. upaya kesehatan } \\
\text { masyarakat: promotif, } \\
\text { preventif, kuratif, } \\
\text { rehabilitative. }\end{array}$ \\
\hline
\end{tabular}




\begin{tabular}{|c|c|c|c|}
\hline No & Sebelum Rekonstruksi & Kelemahan-kelemahan & Hasil Rekonstruksi \\
\hline 2 & $\begin{array}{l}\text { Pasal } 50 \\
\text { Dokter atau dokter gigi dalam } \\
\text { melaksanakan praktik kedokteran } \\
\text { mempunyai hak : } \\
\text { a.memperoleh perlindungan hukum } \\
\text { sepanjang melaksanakan tugas } \\
\text { sesuai dengan standar profesi dan } \\
\text { standar prosedur operasional; } \\
\text { b.memberikan pelayanan medis } \\
\text { menurut standar profesi dan standar } \\
\text { prosedur operasional; }\end{array}$ & $\begin{array}{l}\text { 2.1. Pasal } 50 \text { huruf a, } \\
\text { tidak sinkron dengan } \\
\text { Pasal } 45 \text { UU No. } 44 \\
\text { Tahun } 2009 \text { tentang } \\
\text { Rumah Sakit. } \\
\text { Pasal } 45 \text { Undang- } \\
\text { undang Rumah Sakit } \\
\text { diatur bahwa: } \\
\text { (1). "Rumah Sakit tidak } \\
\text { bertanggung jawab } \\
\text { secara hukum apabila } \\
\text { pasien dan/atau } \\
\text { keluarganya menolak } \\
\text { atau menghentikan } \\
\text { pengobatan yang dapat } \\
\text { berakibat kematian } \\
\text { pasien setelah adanya } \\
\text { penjelasan medis yang } \\
\text { komprehensif. } \\
\text { (2). Rumah Sakit } \\
\text { tidak dapat dituntut } \\
\text { dalam melaksanakan } \\
\text { tugas dalam rangka } \\
\text { menyelamatkan nyawa } \\
\text { manusia." } \\
\text { 2.2.Pasal } 50 \text { huruf } \\
\text { b, Hak dokter juga } \\
\text { Kewajiban dokter }\end{array}$ & $\begin{array}{l}\text { Pasal } 50 \\
\text { Dokter atau dokter gigi } \\
\text { dalam melaksanakan praktik } \\
\text { kedokteran mempunyai hak: } \\
\text { a.memperoleh perlindungan } \\
\text { hukum tidak dapat dituntut } \\
\text { sepanjang melaksanakan } \\
\text { tugas sesuai dengan standar } \\
\text { profesi dan standar prosedur } \\
\text { operasional; } \\
\text { b.dihilangkan }\end{array}$ \\
\hline 3 & $\begin{array}{l}\text { Pasal } 75 \text { ayat (1): } \\
\quad \text { Setiap dokter atau dokter gigi } \\
\text { yang dengan sengaja melakukan } \\
\text { praktik kedokteran tanpa memiliki } \\
\text { surat tanda registrasi sebagaimana } \\
\text { dimaksud dalam Pasal } 29 \text { ayat (1) } \\
\text { dipidana dengan pidana penjara } \\
\text { paling lama } 3 \text { (tiga) tahun atau denda } \\
\text { paling banyak Rp } 100.000 .000,00 \\
\text { (seratus juta rupiah) }\end{array}$ & $\begin{array}{l}\text { a.Merupakan standar } \\
\text { kewenangan untuk } \\
\text { praktik dokter, setelah } \\
\text { lulus uji kompetensi } \\
\text { atau perpanjangan } \\
\text { surat tanda regristrasi. } \\
\text { b. Supaya tidak coba- } \\
\text { coba. }\end{array}$ & $\begin{array}{l}\text { Pasal } 75 \text { ayat (1): } \\
\quad \text { Setiap dokter atau } \\
\text { dokter gigi yang dengan } \\
\text { sengaja melakukan praktik } \\
\text { kedokteran tanpa memiliki } \\
\text { surat tanda registrasi } \\
\text { sebagaimana dimaksud } \\
\text { dalam Pasal } 29 \text { ayat (1) } \\
\text { dipidana dengan pidana } \\
\text { penjara paling lama } 3 \text { (tiga) } \\
\text { tahun dan denda paling } \\
\text { banyak Rp } 100.000 .000,00 \\
\text { (seratus juta rupiah). }\end{array}$ \\
\hline 4 & $\begin{array}{l}\text { Pasal } 76, \text { Setiap dokter atau dokter } \\
\text { gigi yang dengan sengaja melakukan } \\
\text { praktik kedokteran tanpa memiliki } \\
\text { surat izin praktik sebagaimana } \\
\text { dimaksud dalam Pasal } 36 \text { dipidana } \\
\text { dengan pidana penjara paling lama } 3 \\
\text { (tiga) tahun atau denda paling banyak } \\
\text { Rp100.000.000,00 (seratus juta } \\
\text { rupiah). }\end{array}$ & $\begin{array}{l}\text { Merupakan ijin sarana } \\
\text { praktik dokter. }\end{array}$ & $\begin{array}{l}\text { Pasal } 76, \text { Setiap dokter } \\
\text { atau dokter gigi yang } \\
\text { dengan sengaja melakukan } \\
\text { praktik kedokteran tanpa } \\
\text { memiliki surat izin praktik } \\
\text { sebagaimana dimaksud } \\
\text { dalam Pasal } 36 \text { dipidana } \\
\text { dengan pidana penjara } \\
\text { paling lama } 3 \text { (tiga) tahun } \\
\text { dan denda paling banyak } \\
\text { Rp100.000.000,00 (seratus } \\
\text { juta rupiah) }\end{array}$ \\
\hline
\end{tabular}




\begin{tabular}{|c|c|c|c|}
\hline No & Sebelum Rekonstruksi & Kelemahan-kelemahan & Hasil Rekonstruksi \\
\hline 5 & $\begin{array}{l}\text { Pasal } 79 \text {, Dipidana dengan pidana } \\
\text { kurungan paling lama } 1 \text { (satu) } \\
\text { tahun atau denda paling banyak } \\
\text { Rp50.000.000,00 (lima puluh juta } \\
\text { rupiah), setiap dokter atau dokter gigi } \\
\text { yang: } \\
\text { a. dengan sengaja tidak memasang } \\
\text { papan nama sebagaimana dimaksud } \\
\text { dalam Pasal } 41 \text { ayat (1); } \\
\text { b.dengan sengaja tidak membuat } \\
\text { rekam medis sebagaimana dimaksud } \\
\text { dalam Pasal } 46 \text { ayat (1); atau } \\
\text { c.dengan sengaja tidak memenuhi } \\
\text { kewajiban sebagaimana dimaksud } \\
\text { dalam Pasal } 51 \text { huruf a, huruf b, huruf } \\
\text { c, huruf d, atau huruf e } \\
\text { Pasal } 79 \text {, Dipidana dengan pidana } \\
\text { kurungan paling lama } 1 \text { (satu) } \\
\text { tahun atau denda paling banyak } \\
\text { Rp50.000.000,00 (lima puluh juta } \\
\text { rupiah), setiap dokter atau dokter gigi } \\
\text { yang: } \\
\text { a. dengan sengaja tidak memasang } \\
\text { papan nama sebagaimana dimaksud } \\
\text { dalam Pasal } 41 \text { ayat (1); } \\
\text { b.dengan sengaja tidak membuat } \\
\text { rekam medis sebagaimana dimaksud } \\
\text { dalam Pasal } 46 \text { ayat (1); atau } \\
\text { c.dengan sengaja tidak memenuhi } \\
\text { kewajiban sebagaimana dimaksud } \\
\text { dalam Pasal } 51 \text { huruf a, huruf b, huruf } \\
\text { c, huruf d, atau huruf e } \\
\text { Pasal } 79 \text {, Dipidana dengan pidana } \\
\text { kurungan paling lama } 1 \text { (satu) } \\
\text { tahun atau denda paling banyak } \\
\text { Rp50.000.000,00 (lima puluh juta } \\
\text { rupiah), setiap dokter atau dokter gigi } \\
\text { yang: } \\
\text { a. dengan sengaja tidak memasang } \\
\text { papan nama sebagaimana dimaksud } \\
\text { dalam Pasal } 41 \text { ayat (1); } \\
\text { b.dengan sengaja tidak membuat } \\
\text { rekam medis sebagaimana dimaksud } \\
\text { dalam Pasal } 46 \text { ayat (1); atau } \\
\text { c.dengan sengaja tidak memenuhi } \\
\text { kewajiban sebagaimana dimaksud } \\
\text { dalam Pasal } 51 \text { huruf a, huruf b, huruf } \\
\text { c, huruf d, atau huruf e }\end{array}$ & \begin{tabular}{|l|} 
a.Pelanggaran \\
administrasi dikenai \\
sanksi penjara. \\
Dokter harus \\
selalu menjaga \\
kompetensinya \\
dengan terus menerus \\
mengikuti pendidikan \\
berkelanjutan (Untuk \\
masalah ini mestinya \\
tidak perlu ada sanksi \\
pidana). \\
b.Sesuai keputusan MK \\
No. 40/PUU-X/2012 \\
MK
\end{tabular} & $\begin{array}{l}\text { Pasal 79, Dipidana dengan } \\
\text { denda paling banyak } \\
\text { Rp50.000.000,00 (lima puluh } \\
\text { juta rupiah), setiap dokter } \\
\text { atau dokter gigi yang: } \\
\text { a.dengan sengaja tidak } \\
\text { memasang papan nama } \\
\text { sebagaimana dimaksud } \\
\text { dalam Pasal } 41 \text { ayat (1); } \\
\text { b.dengan sengaja tidak } \\
\text { membuat rekam medis } \\
\text { sebagaimana dimaksud } \\
\text { dalam Pasal } 46 \text { ayat (1); } \\
\text { atau } \\
\text { c.dengan sengaja tidak } \\
\text { tidak memenuhi kewajiban } \\
\text { sebagaimana dimaksud } \\
\text { dalam Pasal } 51 \text { huruf a, } \\
\text { huruf b, huruf c, huruf d, atau } \\
\text { huruf e. }\end{array}$ \\
\hline
\end{tabular}

\section{Kesimpulan dan Saran}

Dalam penyelesaian sengketa medis antara dokter dan pasien sebagaimana tertuang dalam Pasal 50 Undang-Undang No. 29 Tahun 2004 tentang Praktik Kedokteran dan Pasal 57
Undang-Undang No. 36 Tahun tentang Tenaga Kesehatan belum sepenuhnya memberikan perlindungan bagi dokter, karena dalam praktiknya penanganan kasus dugaan malpraktik oleh penyidik kepolisian tentunya akan menggunakan 
tatacara atau prosedur yang ada di KUHAP sebagai acuannya, ini dikarenakan UUPK tidak mengatur bagaimana beracaranya apabila ada dugaan dokter melanggar pasal-pasal dalam UUPK. Kondisi ini memungkinkan manakala dokter sudah melaksanakan semua prosedur dan bekerja sesuai standar tetapi hasilnya pasien menderita cacat atau bahkan meninggal dunia karena prinsip res ipsa loquitur tetap akan diproses secara hukum jika ada laporan pasien atau keluarga pasien ke penyidik, ada generalisasi setiap adverse event (kejadian tidak diharapkan) adalah malpraktik.

Studi ini mempunyai implikasi yang bersifat teoritis yang terkait dengan dokter sebagai profesional wajib melaksanakan norma etika yang berlaku dalam organisasi profesi dokter (Ikatan Dokter Indonesia), norma disiplin dan norma hukum. Sehingga dirasakan semua tindakan dokter dapat dipertanggungjawabkan baik dari aspek prinsip, standar dan aturan profesi dokter. Setiap kasus klinik yang dihadapi seorang dokter terdapat aspek etik, aspek medis dan aspek yuridis yang tidak dapat dipisahkan sehingga diperlukan cara yang bijaksana untuk mengambil keputusan klinis. Pemerintah dan DPR diharapkan dapat melakukan penyempurnaan terhadap Undang-Undang No. 29 Tahun 2004 tentang Praktik Kedokteran, dengan dibuatnya peraturan tentang "tatacara ber-acara" mulai dari penyelidikan, penyidikan, penuntutan jika diperlukan dengan sampai putusan. Proses hukum yang sekarang dilaksanakan sangat melelahkan, memerlukan waktu yang cukup lama, biaya yang tidak sedikit.

\section{Daftar Pustaka}

Baru, Penerjemah : Tjetjep Rohendi Rohidi, Badan Pembinaan Hukum Nasional, Pengkajian Hukum Tentang Perlindungan Hukum Bagi Upaya Menjamin Kerukunan Umat Beragama, Kementerian Hukum Dan Hak Asasi Manusia, Jakarta, 2011UI Press, Jakarta, 2009

Black's Law Dictionary, Bryan A. Garner Editor in Chief Ninth Edition, st. Paul. MN : West Pubushing. Co, 2009

Breen, J, K et.al, Good Medical Practice Professionalism, Ethics And Law, Cambridge University Press, New york, 2010

Hadjon P. M., Perlindungan Hukum Bagi Rakyat di Indonesia, Bina IImu, Surabaya, 1987

Hans Kelsen "Teori hukum murni-dasasr-dasar ilmu hukum normative" terjemahan The fure of teory : Barkely University of California press :1978 : Nusa Media, Bandung, 2010

Hasyim, Umar, Mencari Takdir, Penerbit Ramadhani, Solo, 1983

http://wordpress.com/2012/10/21/bisnis-dan-etika/, 21 Desember 2014.

https://seanochan.wordpress.com/2013/04/19/hadis-tentang-takdir/. Diakses 18 Agustus 2016.

http://www.merdeka.com/peristiwa/5-kasus-malpraktek-dalam-dunia-kedokteran.html, diakses 5 Desember 2014

http://legal-dictionary.thefreedictionary.com/Strict+Liability, diakses 5 Desember 2014

Jonsen, A, R, Siegler, M, Winslade, W, J, Clnical Ethics, A Practical Approach to Ethical Decision in Clinical Medicine, McGraw-Hill Medical Publishing Division, New York, 2006

Kitab Undang-Undang Hukum Pidana

Undang-Undang No. 29 Tahun 2004 tentang Praktik Kedokteran. 